Kimura, K. \& Beidler, L. M. (1956). Amer. F. Physiol. 187, 6 1о.

Kolmer, W. (1927). Hanb. milkr. anat. Menschen, no. I, vol. 3, p. I 54.

Kramer, A. (1955). In Handbook of Food and Agriculture. [F. C. Blanck, editor.] New York: Reinhold Publishing Corp.

Peryam, D. R. (I958). In Flavor Research and Food Acceptance, p. 49, [Arthur D. Little Inc., sponsor.] New York: Reinhold Publishing Corp.

Pfaffmann, C. J. (1955). F. Netirophysiol. I8, 429.

\title{
The effects of industrialization, recent food legislation and advertising on food habits in Britain
}

\section{By Magnus Pyкe, The Distillers Company Limited, Glenochil Research Station, Menstrie, Clackmannanshire}

Industrialization could be expected to affect food habits in Britain in a number of ways. The substitution of mechanical power for muscular effort might reduce the demand for calories and hence change the kinds of food eaten and the nature and possibly the frequency of the meals taken. The increase in industrial productivity and the introduction of automatic processes and labour-saving devices would tend to save labour and reduce the hours of work, increase real wages and consequently improve the standard of living, which also might affect the kind of foods eaten. A third factor arising from industrialization, however, is that though the demands for muscular effort by the individual worker may be reduced, the call for increasing numbers of workers and particularly for more women becomes more insistent. Clearly the removal of women from the kitchen to the factory or office must exert a very direct effect on the food habits of the population.

At the same time as these influences are coming to bear on the population in an increasingly industrialized Britain, advances in food technology also bring about a change in eating habits. New developments in packaging and processing, canning, dehydration, the rapid advance in the technology of food freezing and the invention of entirely new foods all exert an influence in changing dietary habits. It is at this point that advertising has a part to play in popularizing newly developed foods.

\section{The effect of changes in industrial work on food habits}

Throughout the present century there has been an almost continuous reduction in the official working hours until today the standard working week is approaching $40 \mathrm{~h}$. In a number of industries the 5 -day week has also been adopted. Nevertheless no reliable information has been found about the total time actually worked and the number of people who work overtime on Sundays. Consequently, it has not been possible to estimate to what extent increasing industrialization is reducing maximum energy demands or, indeed, whether it is doing so at all.

The possibility that new automatic machinery may not in fact reduce the worker's energy demands and hence change the calorific value of his diet was shown by Scholz (1957-8) in Germany. In a study of men and women making medium weight castings in seven different foundries, he found that more than half the workers were 
physically overloaded and that modern machines were sometimes badly designed and thus imposed an unnecessary amount of 'static work' owing to the inappropriate height and arrangement of their control levers. He also found that, whereas the introduction of a fully automatic 'joggling machine' increased the output of disc wheel mouldings from 60 to 182 pieces, the installation of this modern automatic plant did not reduce labour; on the contrary, the energy demands on the man working it rose from $1800 \mathrm{kcal}$ to $2030 \mathrm{kcal}$ per shift.

It seems at the present time that the physical demands on industrial workers, and their consequent needs for food calories may be subject to influences in two directions. Overtime and badly designed plant, even if it is largely automatic, may, as shown by Scholz, increase the energy demands. On the other hand, efforts are being directed, as described by Clark (1954) and by Murrel (1954), to design such things as seats and working spaces at machines and to place the controls in such a way that the effort needed to work them is reduced. The two influences affecting modern industrial workers are further apparent in recent studies (Taylor \& Garvey, I959) of the contrasting pressures of industrial training schemes on the one hand, designed to adapt the behaviour of work-people, by a polite form of the Procrustean principle, to fit the demands of their machines and, on the other hand, of the socalled 'human engineer' whose object is to modify the machine and the working environment to suit the worker.

A trend in modern industry is the installation of increasingly elaborate and expensive machinery. In order to obtain a satisfactory economic return for the financial investment involved, it is then necessary to work the plant continuously and the operatives must consequently work shifts. This arrangement has a direct and immediate effect on their dietary habits. Furthermore, as is shown in Table $r$, the precise timing of the beginning and end of the shifts may also be important if it conflicts with accepted meal times.

\section{Industrialization in food manufacture}

Food habits have been changing quite rapidly since the prewar days of the 1930's owing to innovations in industrialization in food manufacture. The production of Table I. Effect of shift-timing on the number of meals of railway workers (from Pyke, 1950)

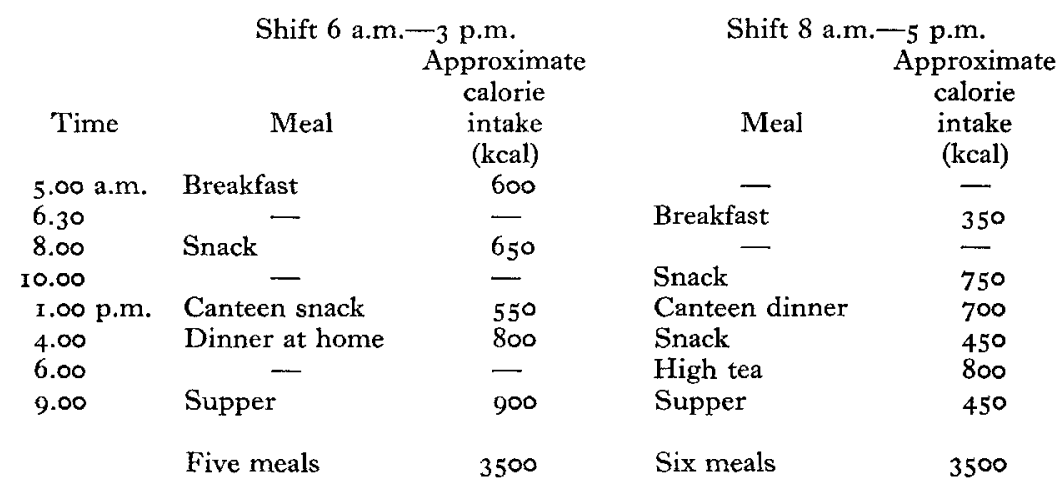


canned food increased in Great Britain from 297000 tons in 1938 to 565000 tons in 1953. During the same period the consumption of canned meat rose from 5.3 to IO. $\mathrm{r} \mathrm{lb} /$ head, at which level it constituted $10 \%$ of the total meat consumption. Similarly, consumption of canned fruit and canned vegetables rose from 9.8 and $5.1 \mathrm{lb}$ to 12.3 and $10.2 \mathrm{lb} /$ head respectively (Commonwealth Economic Committee, 1955). The sales of canned and packet soup now represent an expenditure of $f 3^{\circ}$ million a year and are equivalent to one and a half platefuls a week per head of the population (Anonymous, $1960 b$ ). A particular example from this general trend is that the demand for canned foods made by the H. J. Heinz Co. Ltd has doubled every year since 1945, until in 1959 the average British consumer ate more tins of baked beans than the average American (Anonymous, 1959a).

One of the most striking technical developments in industrial food manufacture and one which is having a direct effect on food habits is the expanding output of frozen foods. Between 1957 and 1959, sales of frozen foods in Great Britain doubled (Anonymous, rg6oa) to reach a value of $\AA_{3} 6$ million a year. A good example of what is happening is given by the growth of the market for frozen fish. Traditionally, the marketing of fish as food is an inefficient process in Great Britain. After quite prolonged residence under not particularly satisfactory storage conditions in a trawler, all the fish landed still has to go through the antiquated auction market on the fish dock at each port. The variability in quality and the gradual increase in price largely arising from this neglect of efficient modern methods of food manufacture have been reflected in the change in British food habits shown by a fall in the consumption of fish from $4 \mathrm{I} \mathrm{lb} /$ head year before 1914 to $2 \mathrm{I} \mathrm{lb} /$ head year in 1957 . But recently, although the total sales of fish have continued to fall, for example from $26 \mathrm{lb} / \mathrm{head}$ year in 1952 to $18.5 \mathrm{lb}$ in 1958 , sales of quick-frozen fish have risen from $3 \%$ of the catch in 1953 to $1 \mathrm{I} \%$ in 1958 and to an estimated $14 \%$ in 1960 . This has been brought about by several technical innovations. Trials have been made of quickfreezing the catch at sea, and at least two very large firms are examining the possibility of running quick-freeze packing stations in factory ships. Another has introduced the big innovation of contracting to buy and process a trawler's entire catch and thus shortcircuit the technically undesirable auction on the fish quay at dawn (Anonymous, 1960c).

Frozen fish, in its modern, packaged, branded and advertised forms of fish fingers and fillets, although it has not so far made a radical change in food habits in Britain is increasing in importance while the consumption of fish as it has heretofore been known is declining. The frozen pack saves time but costs more and is therefore justly changing dietary customs in the millions of homes where the housewife goes out to work in industry and there is more and more money and less and less time. Similar influences lie behind the sharp rise in the British consumption of frozen peas, which constitute $34 \%$ of all frozen foods. The price of $\mathrm{I} \frac{1}{2} \mathrm{lb}$ of fresh peas may be as little as $3 \mathrm{~d}$ or as much as Is. $6 \mathrm{~d}$. at the greengrocer. They yield, say, ro oz in the saucepan. Whereas this amount could be bought for $6-7 \frac{1}{2} \mathrm{~d}$. as the less satisfactory 'processed' peas, for IO-IId. as dried peas, or for IId-IS. $2 \mathrm{~d}$. as canned 
'garden' peas, it is probably worth the is. I Id. it costs 'fresh frozen' to the industrial housewife in terms of convenience and quality.

\section{Food habits and advertising}

In 1949 , I had the hardihood to coin a so-called 'dietary law' stating: 'if there is a nutritional need for an article of diet, the free play of social forces within a community will in due time cause that article to be invented' (Pyke, 1949). Examples cited then were sausages in Germany as a vehicle for animal proteins when meat supplies were restricted, and, in the first century A.D., the invention of haggis by Roman soldiers campaigning in Scotland where the preparation of meals might be disturbed. A converse to this law would be that when no nutritional or dietary need exists, pressure exerted by advertising or other means of persuasion is unlikely to have any marked or permanent effect on dietary habits.

It is a well-known principle of economics that, as the effective wealth of the community rises, the consumption of bread and other cereals falls and is counterbalanced by an increased use of more highly prized animal foods. From time to time the millers and bakers have mounted massive advertising campaigns to hold back or reverse this trend. Persuasive, attractive and truthful arguments have been used. It is highly doubtful, however, whether these efforts are effective. In contrast, the major change in food habits in Britain exemplified by the adoption of cornflakes and other prepared breakfast foods shows the influence of advertising of quite a different character when it is supported by nutritional need and social pressures.

Cornflakes were invented in 1898 by Dr John Kellogg as part of the confused and quasi-religious activities of the Seventh Day Adventists in America. Other similar health-food products were Granula, Granola, Malta Vita, Vim, Force, Javril and Cero-Fruto. Dr Kellogg also started the Sanitas Nut Food Company to market Protose, claimed to be the equivalent of beef steak, and Nuttose, allegedly equal to veal (Carson, I959). In 1956, \$4 I million was spent on advertising in the United States to sell $\$ 379$ million-worth of prepared breakfast foods. In I903, C. W. Post used advertisements whose tenor was 'you can recover from any ordinary disease by discontinuing coffee and poor food and using Postum Food Coffee and Grape Nuts'. And it was only in I95 I, 37 years after his death, that the company manufacturing these products agreed to a ruling of the United States Federal Trade Commission to abandon their advertising claims that drinking coffee instead of Postum caused 'divorces, business failures, factory accidents, juvenile delinquency' and much else.

Carson pointed out, however, that in spite of extravagant claims ranging from 'full of Vegetable Phosphorus that makes children grow like magic', 'gives the brain all the phosphorus it can use in heavy thinking' (Ralston Health Food), to 'makes red blood' (Grape Nuts), 'brain, nerve and muscle food' (Hardy Food), and despite the fact that in the early years there was no relationship between nutrition and price, these ready-to-serve foods offered certain advantages: they added variety and flavour, they were fresh and clean, they were storable, and they could be eaten straight from the box. That is to say, the change in food habits leading to the eating of such 20 (I) 5 
products was only partly dependent on advertising and was affected to an even lesser degree by the nature of the advertisements and whether they offered added vitamins or plated knives and forks. To a greater extent the change was dependent on the social need for a light palatable article not requiring work in the kitchen.

\section{The effect of the employment of women in industry}

The number of wives in Great Britain who are engaged in industrial work or in the office work arising from it has doubled in the last generation and at the present time one married woman in three goes out to work (Anonymous, 1960a). This practice clearly exerts a direct influence on food habits from the fact that spare housekeeping money has now replaced spare time in an increasing number of homes.

Between 1953 and $195^{8}$, per capita expenditure on food in Britain increased by $25 \%$ whereas prices only increased by $18 \%$. It is deduced that a significant part of this increased expenditure is due to a change in food habits. Sales of packaged foods have been rising more sharply than total spending on food (Anonymous, r960a). Wrapped and washed fresh meat and vegetables, sliced bread and sliced cheese are all gaining sales because they save work in the kitchen. The trend is now towards the production and sale of complete dishes, for example, curry and rice or turkey pie, or even complete meals canned or frozen. British manufacturers are, however, hesitating to go to the limit already attained in the United States where packaged 'television dinners' are marketed to meet the needs of a fully industrialized society.

It is not easy to assess the magnitude of the changes in dietary habits due to the increasing employment of women in industry and the corresponding secular fall in the size of families. For example, it was found by Warren (1958) that more than $60 \%$ of men and more than $80 \%$ of women still eat their midday meal at home. Furthermore, in spite of the growing standardization of life in an industrial community, a wide range of individual and regional differences exists in food preferences (Harper, 1956).

\section{Recent food legislation and food habits}

In a democratic society the laws are in many respects little more than a reflection of existing social trends and to that extent food laws are likely to exert very little effect on food habits in Britain. The licensing laws governing the supply of alcoholic drink are a case in point. It is difficult to decide whether the fall in consumption of alcoholic beverages and the increase in sobriety that has taken place during the last I 00 years has been much affected by regulation of the permitted hours of drinking or whether the increase in wealth, the growth of alternative social interests, and the reduction in heavy manual labour would have produced the same result.

Much of the recent food legislation in this country has been concerned with the quality of different foodstuffs and the way in which they are labelled. The fact that the Food Standards Committee rules against the use of a particular colouring material is unlikely of itself to affect food habits. The result of the legislation will be that the manufacturer uses another dye. The establishment of public-health regulations to 
control the quality of meat pies or ice-cream and to regulate the conditions under which they are manufactured will not so much change food habits but rather render it safe for existing habits to continue. Similarly, legislation dealing with fat extenders, preservatives, anti-oxidants, synthetic flavouring agents and additives of all sorts tends to protect the consumer who is eating the items his habit dictates rather than to initiate new habits.

\section{Conclusions}

Although general information exists about changes in British food habits during recent years, detailed and precise knowledge is not readily available. Apart from the facts collected by the National Food Survey, somewhat more specialized data have been collected on buying habits by market research organizations (Anonymous, I $959 b$ ) from which something of the diversity of food habits within the country can be deduced, for example, that baked beans are more popular in the north of England than they are in Wales. So far as general tendencies are concerned, however, it appears that industrialization is affecting British food habits by changing the social environment of the population and by its influence on the food industries and the products they are able to manufacture. For the rest, the opinion is hazarded that advertising and recent legislation have little permanent effect.

\section{REFERENCES}

Anonymous (1959a). Economist, 23 May, p. 737.

Anonymous (1959b). Buying Habits of Daily Herald Readers. Odham's Press Ltd., Rep. no. 3. London: Odham's Press Ltd.

Anonymous (1960a). Economist, 28 May, p. 887.

Anonymous (1960b). Food Manuf. г May, p. 178 .

Anonymous ( $1960 c$ ). The Observer, ${ }_{5} 5$ May, p. 3 .

Carson, G. (1959). Cornflake Crusade. London: Gollancz.

Clark, R. Le G. (1954). In Human Factors in Equipment Design, p. 5. [W. F. Floyd and A. T. Welford, editors.] London: Lewis.

Commonwealth Economic Committee (1955). Canned Food. London: H.M. Stationery Office.

Harper, R. (1956). Advanc. Sci. 13, 297.

Murrell, K. F. H. (1954). In Human Factors in Equipment Design, p. 1 19. [W. F. Floyd and A. T. Welford, editors.] London: Lewis.

Pyke, M. (1949). Chem. \& Ind. p. $73^{8}$.

Pyke, M. (1950). Industrial Nutrition. London: Macdonald and Evans.

Scholz, H. (1957-8). Ergonomics, I, 30.

Taylor, F. V. \& Garvey, W. D. (1959). Ergonomics, 2, 187.

Warren, G. C. (1958). The Foods We Eat. London: Cassell. 